\title{
Papillary renal cell carcinoma with synchronous ovarian metastasis: a rare entity
}

\author{
Ved Bhaskar, Manoj Kumar, Sunny Goel, Satyanarayan Sankhwar
}

Department of Urology, King George's Medical University, Lucknow, India

Correspondence to Dr Sunny Goel, drsunnygoel09@gmail.com

Accepted 9 May 2017
CrossMark

To cite: Bhaskar $\mathrm{V}$, Kumar $\mathrm{M}$, Goel S, et al. BMJ Case Rep Published Online First: [please include Day Month Year]. doi:10.1136/bcr-2017220764

\section{DESCRIPTION}

A 45 -year-old woman presented with left-lower abdominal lump for the last 3 months. On examination, she had a palpable lump in the left iliac region, $10 \mathrm{~cm}$ in size, firm, non-tender and mobile. Incidentally, another lump was palpable in her left flank which was ballotable. Ultrasonography revealed the presence of a large adnexal mass and showed a concomitant left renal mass. Contrast-enhanced computed tomography abdomen revealed the presence of heterogeneously enhancing space occupying lesion in the mid and lower pole of the left kidney $(10.6 \times 8.8 \times 9.0 \mathrm{~cm})$ and a large heterogeneously enhancing lesion was seen in the left adnexal region $(11.7 \times 8.7 \times 12.2 \mathrm{~cm})$ (figure 1). Para-aortic lymph nodes were enlarged. Cancer antigen (CA) 125 levels were $170 \mathrm{U} / \mathrm{mL}$.

Patient underwent open left radical nephrectomy and excision of the adnexal mass with bilateral salpingo-oophrectomy and hysterectomy via midline vertical incision. On gross inspection, ovarian mass had mixed areas of nodular and cystic appearance, whereas the renal mass was found to be of solid consistency grossly (figure 2). Biopsy report showed the presence of left renal cell carcinoma (papillary variant), Fuhrman nuclear grade 3 and metastases from papillary renal cell carcinoma (RCC) in the adnexal mass (figure 3). Twenty-one of 23 lymph nodes were positive for metastases. Perioperative course was uneventful and the patient was discharged

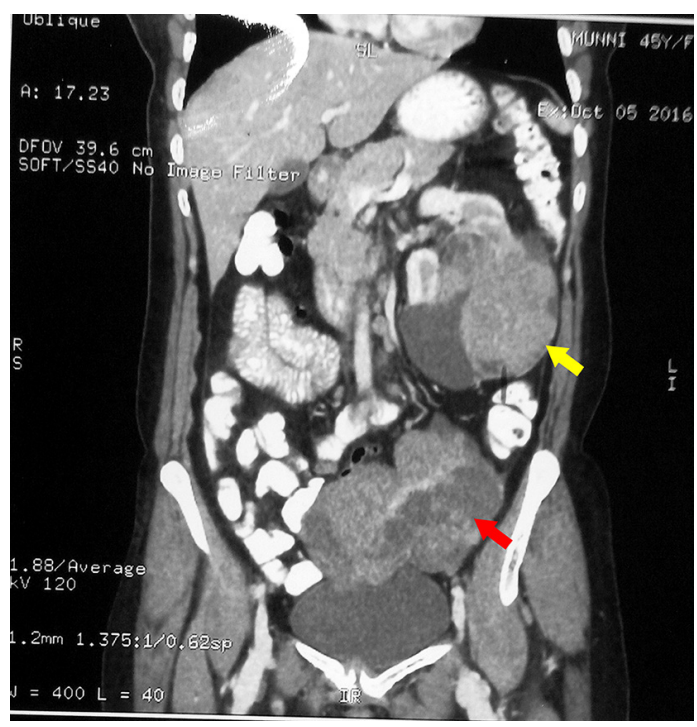

Figure 1 Contrast-enhanced computed tomography abdomen showing concomitant renal and ovarian mass (renal mass marked by yellow arrow, ovarian tumour marked by red arrow).

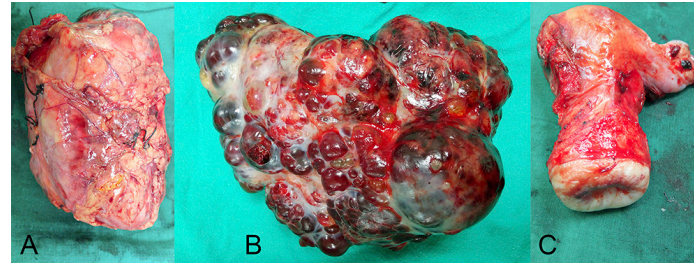

Figure 2 Images of specimen retrieved after radical nephrectomy (A), salpingo-oophrectomy (B) and hysterectomy (C).

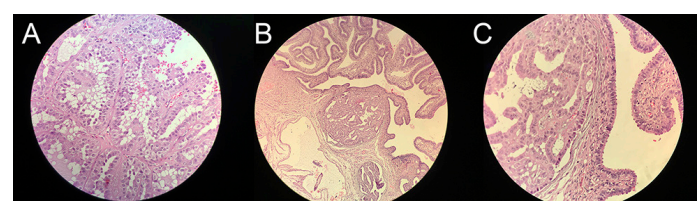

Figure 3 Histopathological slides showing papillary renal cell carcinoma (RCC) (A), metastases to the Fallopian tube $(B)$ and metastases to the Fallopian tube at high power (C).

on postoperative day 7. As per discussion with oncologists, it was decided to keep the patient under strict follow-up at 3-6 monthly intervals. At 3 months follow-up, the patient was completely asymptomatic and ultrasonography showed normal right kidney with empty left renal fossa.

RCC metastasises to unusual sites but rarely to ovary, with 20 cases reported to date, most of them corresponding to clear cell neoplasms. ${ }^{1}$ Only one case of papillary RCC metastasising to the ovary has been reported so far. ${ }^{2}$ We herein present a first case of its kind of papillary renal cell carcinoma with synchronous ovarian tumour which on biopsy proved to be metastasis from the papillary RCC.

\section{Learning points}

- Metastases from renal tumours to ovaries are usually unilateral because of retrograde venous embolisation in unique venous anatomy of renal-ovarian axis, unlike ovarian metastases from other organs which are usually bilateral.

- Primary ovarian tumours are commonly confused with ovarian metastases, due to the more common metachronous presentation of ovarian metastases.

- A dedicated oncopathologist with a good microscopic analysis, often accompanied with immunohistochemical studies, is needed to diagnose such cases. 
Contributors All of the authors declare that they have all participated in the design, execution and analysis of the paper, and that they have approved the final version. Individual contributorship is as follows: VB helped in the concept, design, supervision, processing, writing of the manuscript and critical analysis. MK helped in the concept, design, supervision, processing, writing of the manuscript and critical analysis. SG helped in the supervision, processing, writing of the manuscript and critical analysis. SS helped in the concept, supervision, writing of the manuscript and critical analysis.

Competing interests None declared.

Patient consent Obtained.

Provenance and peer review Not commissioned; externally peer reviewed.
(C) BMJ Publishing Group Ltd (unless otherwise stated in the text of the article) 2017. All rights reserved. No commercial use is permitted unless otherwise expressly granted.

\section{REFERENCES}

1 Masago T, Morizane S, Watanabe T, et al. A case of renal cell carcinoma metastatic to the ovary: a case report and review of the literature. Vol. 4. No. 2. Japan: Springer, 2015.

2 Stolnicu S, Borda A, Radulescu D, et al. Metastasis from papillary renal cell carcinoma masquerading as primary ovarian clear cell tumor. Pathol Res Pract 2007;203:819-22.

Copyright 2017 BMJ Publishing Group. All rights reserved. For permission to reuse any of this content visit

http://group.bmj.com/group/rights-licensing/permissions.

BMJ Case Report Fellows may re-use this article for personal use and teaching without any further permission.

Become a Fellow of BMJ Case Reports today and you can:

- Submit as many cases as you like

- Enjoy fast sympathetic peer review and rapid publication of accepted articles

- Access all the published articles

Re-use any of the published material for personal use and teaching without further permission

For information on Institutional Fellowships contact consortiasales@bmjgroup.com

Visit casereports.bmj.com for more articles like this and to become a Fellow 